BIOMEDICAL AND BIOSOCIAL ANTHROPOLOGY
Official Journal of the International Academy
of Integrative Anthropology
journal homepage: http://bba-journal.com

\title{
Features of gynecological pathology in women of reproductive age from Kyiv region
}

Horban N.Ye., ${ }^{1}$ Dzys N.P., ${ }^{2}$ Lynchak, O. V., ${ }^{3}$ Pokanevych T.M. ${ }^{4}$

${ }^{1}$ State Institution "Institute of Pediatrics, Obstetrics and Gynecology named after Academician O.M. Lukyanov National Academy of Medical Sciences of Ukraine", Kyiv, Ukraine

${ }^{2}$ National Pirogov Memorial Medical University, Vinnytsya, Ukraine

${ }^{3}$ State Institution "Institute of Public Health. OHM. Marzeyev National Academy of Medical Sciences of Ukraine ", Kyiv, Ukraine "Municipal institution of the Kyiv regional council "Kiev regional health center for mothers and children", Kyiv, Ukraine

\section{ARTICLE INFO}

Received: 28 December 2018

Accepted: 29 January 2019

UDC: $618.3-055.2(477-25)$

\section{CORRESPONDING AUTHOR}

e-mail: ngorban@i.ua Horban N. Ye.
One of the main conditions for the birth of a healthy baby is the gynecological health of the mother. For this reason, the purpose of the work was to assess the state of gynecological health of women in the Kyiv region. In this work, we used the data of departmental statistical reporting of the Ministry of Health of Ukraine about the number of cases of gynecological pathology from 2010-2017. The number of women of the corresponding age was determined according to the State Statistics Service of Ukraine. The relative risk of pathology (taking into account the $95 \%$ confidence interval) from 2010-2013, 2014-2017 in the Kyiv region was evaluated in comparison with the general indicators in Ukraine as well as from 2014-2017 compared to 2010-2013 in the Kyiv region and general data in Ukraine. Separately for the Kyiv region, the frequency of gynecological pathology was determined among women of reproductive age (707 women), who visited Municipal Institution of Kyiv Regional Council "Kyiv Regional Centre for the Mother and Child Health Defense" from 2014 to 2017. The average age of women was 31.66 \pm 0.37 . In most cases, the residents of the Kyiv region were diagnosed with chronic inflammatory diseases of the pelvic organs (salpingitis, $21.6 \%$ ). The relative risks of the occurrence of such diseases were determined in the region, compared with Ukraine, and over time. Those, who had menstrual disorders, hyperproliferative processes of the endometrium were more often recorded $(10.8 \%$ versus $3.1 \%, p<0.01)$, and those with inflammatory processes of the pelvic organs more often had cervical dysplasia $(19.8 \%$ versus $4.7 \%, p<0.001)$, chronic diseases of the genitourinary system $(7.1 \%$ versus $3.2 \%, p<0.05)$ and digestive organs $(17.3 \%$ versus $9.6 \%, p<0.01)$, which indicates a possible pathogenetic role of the inflammatory factor in the development of gynecological pathology. The relative risk of gynecological diseases among the women in the Kyiv region showed that the greatest attention is needed to improving the diagnostics of infertility and endometriosis, as well as the prevention and treatment of salpingitis and uterine cancer. Women with menstrual disorder during their visit to a gynecologist should be checked for the presence of hyperproliferative pathology and, in case a woman is diagnosed with other chronic diseases, they should be offered treatment of these areas of inflammation, which can further positively affect their reproductive health.

Keywords: gynecological pathology, reproductive health, menstrual disorders, inflammatory factor.

\section{Introduction}

In the face of economic difficulties, high mortality rates, and declining birth rates, reproductive health issues are being raised, which has been the focus of international attention for some time now and is being implemented by the "Sexual and Reproductive Health Action Plan" (Until
Europe's sustainable development strategy is achieved by 2030 , no one is left behind) [21]. The issue of infertility has been kept by the palm of primes with a prevalence from $9 \%$ to $18 \%$ of the total population [2], creating a significant financial burden even in countries with high levels of 
economy [4, 11]. Parallel to the current medical and social problem is hyperproliferative pathology of the endometrium with high specific gravity in the structure of gynecological morbidity, the risk of its malignant transformation $[3,14,17]$ and inflammatory diseases of the female genital area, in which some positive changes have been achieved. But today, the situation remains unstable, debatable and in need of further search for solutions [5, 12, 13]. Regarding our country, in 1999-2003 the program of genetic monitoring was implemented on the territory of Kyiv region, and from 2009 the registers of birth defects in newborns, spontaneous abortions and infertility continued to operate, which made it possible to assess the level of genetically conditioned pathology and to determine its level and priority factors of its formation $[10,18]$. But, it should not be forgotten that the main factor at birth of a healthy baby (namely, it should be the result of the activity of the gynecological service) is its healthy mother, including - in the issues of the gynecological sphere. This issue is dedicated to this study, which according to the Ministry of Health of Ukraine estimated the level of gynecological pathology in the Kyiv region in comparison with Ukraine in general and characterized gynecological pathology according to the Municipal Institution of Kyiv Regional Council "Kyiv Regional Centre for the Mother and Child Health Defense" (MI KRC KRCMCHD).

The purpose of the work was to assess the gynecological health of women in the Kyiv region.

\section{Materials and methods}

Number of women (general group and group of first detected) with urogenital system diseases, menstrual disorders (MD), salpingitis, endometriosis, infertility, urogenital mycoplasmosis, chlamydial infection and cancer of the uterus taken from $\mathrm{MOH}$ Ukraine published in the collections "Health status of the female population in Ukraine" for 2010-2017.

The number of women of the appropriate age was determined according to the State Statistics Service of Ukraine. Estimated relative risk (RR) of pathology in 20102013, 2014-2017 in the Kyiv region compared with the general indicators in Ukraine and in the period 2014-2017 compared to 2010-2013. Estimated the limits of $95 \%$ confidence interval. If both the upper and lower bounds were on one side of 1 (ie, the confidence interval does not include 1 ), then we concluded that the statistical significance of the detected difference with probability $p<0.05$. If the lower bound was $95 \%$ of the confidence interval less than 1 , and the upper bound was greater, we concluded that there was no statistical significance of the effect of the factor on the incidence of pathology, regardless of the value of $R R(p<0.05)$ [19].

Compared to the usual "p" significance assessment, 95\% confidence intervals are more consistent with decisionmaking practice, because it is possible to take into account the value of the indicator rather than simply the fact that there is a difference between the indicators [22].
The frequency of gynecological pathology among women of fertile age (707 women) who went to the MI KRC KRCMCHD for 2014-2017 was determined separately for the Kyiv region. The average age of women was $31.66 \pm 0.37$ years old.

\section{Results}

As of January 1, 2018, the population of Kyiv Region (estimated) was 1754284 inhabitants. In 2017, the population decline in the Kyiv region was more rapid than in the country as a whole (-6.3 vs. -5.1 per 1000 population), with an average life expectancy at birth slightly lower (70.46 versus 71.98 years), the mortality rate was higher (1203.8 versus 1052.4 per 100 thousand people) [16]. But the marital activity of the population of the region is higher: the higher total fertility rate (1,412 against 1,374 in Ukraine per woman) and age-related fertility rates (the largest difference was observed among 20-24 year-old women: 82.1 versus 79.5 live births per 1000 women). In addition, as of January 1 , 2018 , the proportion of people 18 years and older in the Kyiv Region is lower than in the country as a whole $(80.8 \%$ vs. $82.0 \%)$ at the expense of a larger proportion of children (19.2\% versus $18.0 \%$ for children ages $0-17$ ).

That is, against the background of negative natural growth and low average life expectancy, the Kyiv region has the potential for reproduction, and precisely for its preservation and should be directed to providing medical care to the population, in particular women of reproductive age.

In the Kyiv Region, 2.995 \pm 0.030 patients among 1000 women of reproductive age $(4.072 \pm 0.007 \%$ in Ukraine) encountered infertility problems in 2010-2017. The frequency of menstrual disorders (MD), which is one of the leading pathologies of the female genital area, in 2010-2017 was $13.86 \pm 0.07$ among 1000 women of fertile age (15.69 \pm $0.01 \%$ in Ukraine). The frequency of the first detected MD was $9.122 \pm 0.053 \%$ o (10.039 $\pm 0.001 \%$ in Ukraine).

Salpingitis met with a frequency of $21.58 \pm 0.07$ and endometriosis $1.270 \pm 0.018$ per 1000 working women ( $17.31 \pm 0.01 \%$ and $3,266 \pm 0.006 \%$ in Ukraine, respectively). The incidence of newly detected salpingitis and endometriosis was $11.64 \pm 0.05 \%$ and $0.541 \pm 0.012 \%$ (9.368 $\pm 0.010 \%$ and $1.249 \pm 0.004 \%$ in Ukraine, respectively).

Uterine cancer met with a frequency of $4.739 \pm 0.028$ per 1000 women 18 years of age and older with a morbidity rate of $0.167 \pm 0.007$ among 1000 working women (3.885 \pm $0.005 \%$ and $0.138 \pm 0.001 \%$ in Ukraine, respectively).

The incidence of infections, including urogenital mycoplasmosis and chlamydial infection, in the Kyiv region was the same $(1.924 \pm 0.018$ and $1.918 \pm 0.018$ per 1.000 women 18 years of age and older) and higher than the overall rate in Ukraine $(1.192 \pm 0.003 \%$ and $0.786 \pm 0.002 \%$ respectively).

If the frequency demonstrates the prevalence of a condition in a group, then the relative risk (RR) indicator is considered as the occurrence of a pathological condition or death in one group of persons relative to another. 
Table 1. Relative risk of some gynecological diseases in women of Kyiv region and Ukraine in 2010-2013 compared to 2014-2017 (times).

\begin{tabular}{|c|c|c|c|c|}
\hline \multirow{2}{*}{ Pathology } & $\mathrm{RR}$ & $\mathrm{Cl}$ & $\mathrm{RR}$ & $\mathrm{Cl}$ \\
\hline & \multicolumn{2}{|c|}{ Kyiv region } & \multicolumn{2}{|c|}{ Ukraine } \\
\hline \multicolumn{5}{|l|}{ Prevalence } \\
\hline Salpingitis & 0.92 & $0.91-0.93$ & 0.88 & $0.88-0.88$ \\
\hline Sterility & 1.05 & $1.01-1.09$ & 0.99 & $0.98-0.99$ \\
\hline Death from cancer of the uterus & 1.06 & $0.90-1.24$ & 0.90 & $0.87-0.93$ \\
\hline MD & 1.09 & $1.07-1.11$ & 1.02 & $1.02-1.02$ \\
\hline Uterine cancer & 1.16 & 1.13-1.19 & 1.04 & $1.03-1.04$ \\
\hline Endometriosis & 1.16 & $1.10-1.23$ & 1.12 & $1.12-1.13$ \\
\hline \multicolumn{5}{|l|}{ Morbidity } \\
\hline Sterility & 0.98 & $0.90-1.06$ & 0.90 & $0.89-0.91$ \\
\hline Salpingitis & 0.99 & $0.98-1.01$ & 0.89 & $0.89-0.89$ \\
\hline Uterine cancer & 1.04 & $0.85-1.26$ & 0.94 & $0.91-0.98$ \\
\hline Mycoplasma genitalium & 1.06 & $1.02-1.10$ & 0.75 & $0.75-0.76$ \\
\hline Endometriosis & 1.07 & $0.98-1.17$ & 1.19 & $1.18-1.20$ \\
\hline Chlamydial infection & 1.10 & $1.06-1.14$ & 0.71 & $0.71-0.72$ \\
\hline MD & 1.24 & $1.21-1.27$ & 1.05 & $1.05-1.05$ \\
\hline
\end{tabular}

The situation with RR of occurrence of some gynecological diseases among women of Kyiv region in 2010-2013 compared to 2014-2017 was in most cases similar to this in Ukraine in general (Table 1). The only exceptions were the increased $\mathrm{RR}$ in the region as opposed to the lowered one in Ukraine:

- the prevalence of infertility (one explanation may be to seek women's counseling as it is a chance to receive extracorporeal fertilization funding at public expense);

- incidence of urogenital mycoplasmosis and chlamydial infection.

But these differences cannot be defined as negative compared to the general situation in Ukraine.

In the Kyiv region, relative to Ukraine, there is an increased relative risk of salpingitis and uterine cancer, although it has been shown that the occurrence of salpingitis over time has decreased, as is the case with uterine cancer. However, judging by the relative risk of death from uterine cancer (it does not differ from Ukrainian), its timely diagnosis leads to an increase in effective treatment and a significant reduction in mortality (see Fig. 1, 2).

Against the background of an increase in RR incidence of urogenital mycoplasmosis and chlamydial infection, the relative risk of these infections in the region compared to Ukraine in general is also shown over time, which is another confirmation of effective work on the prevention of TORCH infections (see Table 1, Fig. 2).

The frequency of MD among women of fertile age residents of the Kyiv region who sought medical care at the MI KRC KRCMCHD during 2014-2017, amounted to $396.3 \pm 18.4 \%$ (Table. 2). This is almost 30 times higher than the same indicator among all women of fertile age, according to the Ministry of Health of Ukraine. But this fact is explained by the fact that the object of the Center's activity is to provide the population with the most qualified obstetric and gynecological help.

For comparison, according to genetic monitoring data (1999-2003) in the Kyiv region, among women who had a miscarriage up to 12 weeks and who gave birth to a healthy baby, MD was recorded at $4.75 \pm 053 \%$ and $2.99 \pm 0.55 \%$ of cases and was determined to be significant in the event of unauthorized miscarriage at an early date $(\mathrm{OR}=1.61$ at confidence interval $(\mathrm{Cl})$ 1.02-2.55) [12].

Among women with MD, the highest number of women complained of having an irregular menstrual cycle - almost every second $49.21 \pm 2.80 \%$ with a frequency of $220.65 \pm$ $15.60 \%$ among all women who applied to the MI KRC $\mathrm{KRCMCHD.} \mathrm{This} \mathrm{figure} \mathrm{is} \mathrm{comparable} \mathrm{to} \mathrm{the} \mathrm{results} \mathrm{of} \mathrm{a} \mathrm{US}$ survey, where MD accounted for $19.1 \%$ of the 20 million visits to gynecological facilities [6].

Menorrhagia, as a diagnosis, was found in every fourth woman with MD $(25.24 \pm 2.44 \%)$ with a frequency of $113.15 \pm 11.91 \%$, algomenorrhea - in every ninth woman with MD $(11.04 \pm 1.76 \%)$ with a frequency of $49.50 \pm 8.16 \%$,

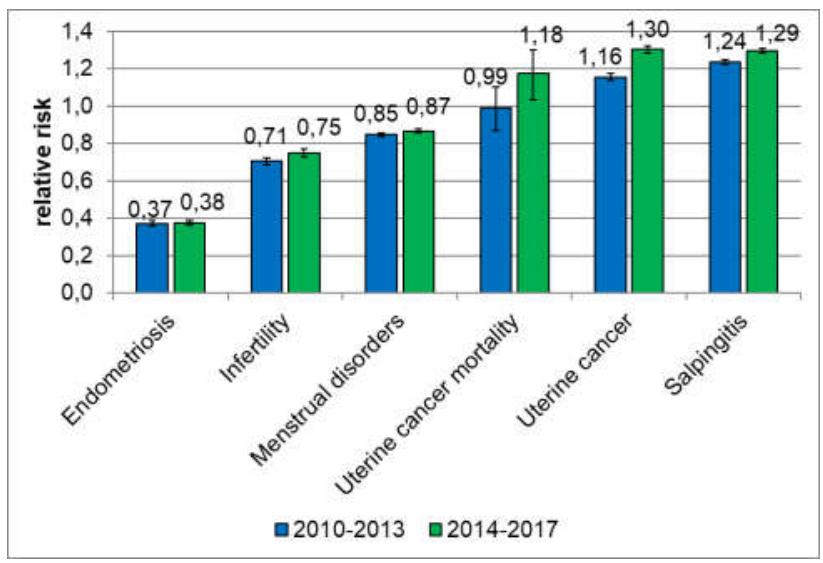

Fig. 1. Relative risk of gynecological diseases (in general, prevalence) in female residents of Kyiv region compared to general indicators in Ukraine.

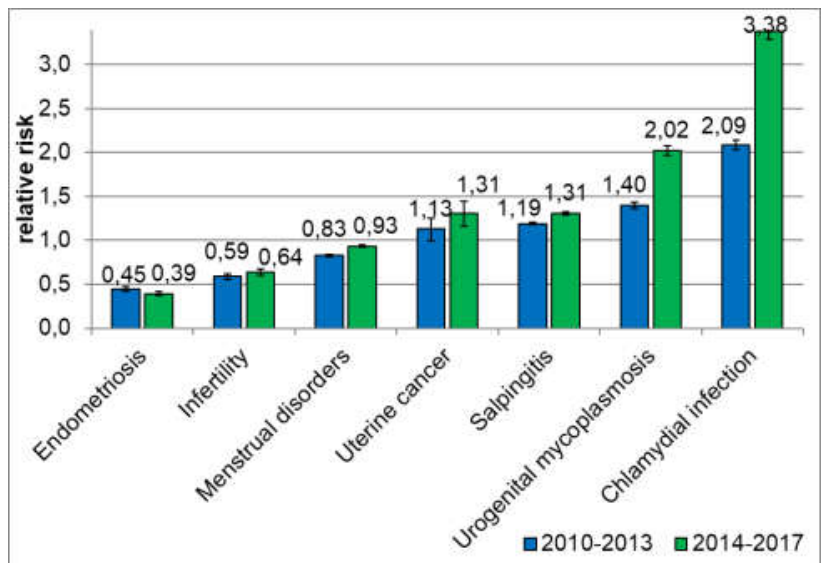

Fig. 2. Relative risk of gynecological diseases (first detected, morbidity) in female residents of Kyiv region compared to general indicators in Ukraine. 
Horban N.Ye., Dzys N.P., Lynchak, O. V., Pokanevych T.M.

Table 2. The number of cases of hyperproliferative pathology among women of different ages with the presence and absence of MD (\%).

\begin{tabular}{|c|c|c|c|c|c|c|}
\hline \multirow{2}{*}{ Hyperproliferative pathology } & \multicolumn{2}{|c|}{$19-49$ (years) } & \multicolumn{2}{c|}{$19-34$ (years) } & \multicolumn{2}{c|}{$35-49$ (years) } \\
\cline { 2 - 7 } & \multicolumn{2}{|c|}{ MD } & \multicolumn{2}{|c|}{ MD } & \multicolumn{2}{c|}{ MD } \\
\cline { 2 - 7 } & Yes & No & Yes & No & No \\
\hline adenomyosis & $5.714 \pm 1.387$ & $2.810 \pm 0.800$ & $4.217 \pm 1.560$ & $1.544 \pm 0.766$ & $7.895 \pm 2.526$ & $4.762 \pm 1.643$ \\
\hline endometrial hyperplasia + uterine polyp & $13.93 \pm 2.07$ & $7.963 \pm 1.310$ & $10.84 \pm 2.41$ & $3.089 \pm 1.075$ & $18.42 \pm 3.63$ & $15.48 \pm 2.79$ \\
\hline endometrial hyperplasia & $8.929 \pm 1.704$ & $5.152 \pm 1.070$ & $6.627 \pm 1.931$ & $2.317 \pm 0.935$ & $12.28 \pm 3.07$ & $9.524 \pm 2.265$ \\
\hline uterine polyp & $6.071 \pm 1.427$ & $4.450 \pm 0.998$ & $4.819 \pm 1.662$ & $1.158 \pm 0.665$ & $7.895 \pm 2.526$ & $9.524 \pm 2.265$ \\
\hline
\end{tabular}

metrorrhagia - in every twelfth woman with MD $(8.202 \pm$ $1.541 \%$ ) with a frequency of $36.78 \pm 7.08 \%$, hypomenstrual syndrome - in every sixteenth woman with MD (6.309 \pm $1.366 \%$ ) with a frequency of $28.29 \pm 6.24 \%$ cases. Almost one in eight women with MD recorded two types of MD $(12.50 \pm 1.98 \%)$, which was $50.78 \pm 8.24 \%$ among 1000 women.

If women were divided into groups by the presence of $M D$, hyperplastic processes were more frequently registered among those who had MD, including endometrial hyperplasia and uterine polyp. This is especially true for women of active reproductive age of 19-34 years. Among patients with MD, hyperproliferative processes were three times more frequent, compared with women with unchanged menstrual cycles $(10.84 \pm 2.41 \%$ vs. $3.089 \pm 1.075 \%, p<0.01)$. In these women, endometrial hyperplasia was three times more recorded $(6.627 \pm 1.931 \%$ vs. $2.317 \pm 0.935 \%, p<0.05)$ and four times more recorded polyps of the uterine $(4.819 \pm 1.662 \%$ vs. $1.158 \pm 0.665 \%, p<0.05)$. Among those women who had MD, compared with women with unchanged menstrual cycles, adenomyosis $(5.714 \pm 1.387 \%$ versus $2.810 \pm 0.800 \%, p=0.08)$ was also more frequently reported (Table 2 ).

These findings are further evidence that MD can be considered as an important clinical marker of gynecological pathology at the pre-hospital stage. When studying the menstrual function of the obstetrician-gynecologist, the following important rules should be followed: try to use the most adaptive scale for both the patient and the doctor to determine the adequacy of the menstrual cycle and find the reasons for its violation [8].

$6.223 \pm 0.909 \%$ of patients were treated with the problem of infertility at the MI KRC KRCMCHD; primary infertility was noted in $4.102 \pm 0.746 \%$ of cases, secondary - in $2.122 \pm$ $0.542 \%$. Salpingitis met with a frequency of $37.91 \pm 1.82 \%$, endometriosis - $0.283 \pm 0.200 \%$.

In general, inflammation of the pelvic organs (chronic salpingitis/oophoritis, chronic metritis, and cervicitis) occurred in every second patient of the MI KRC KRCMCHD $(51.79 \pm 1.88 \%)$, among whom in every tenth, all three pathological conditions were diagnosed $9.9 \%$, in every fourth - two $(24.5 \%)$, and only two thirds of women had one of three pathologies $(65.7 \%)$.

If the fact of the presence of the inflammatory process of the pelvic organs in women is divided into groups, among those who had an inflammatory process were more common:

- history of artificial abortion $(24.18 \pm 2.24 \%$ vs. $16.33 \pm$ $2.00 \%, p<0.01$ );

- cervical dysplasia $(19.78 \pm 2.09 \%$ vs. $4.665 \pm 1.139 \%$, $\mathrm{p}<0.001$ );

- chronic diseases of the genitourinary system, such as chronic pyelonephritis and chronic cystitis $(7.143 \pm 1.350 \%$ vs. $3.207 \pm 0.951 \%, p<0.05$ );

- chronic digestive diseases such as chronic cholecystitis, pancreatitis, gastritis and gallstone disease (17.31 $\pm 1.98 \%$ vs. $9.621 \pm 1.592 \%, p<0.01)$.

\section{Discussion}

In the Kyiv region, with infertility problems in 2010-2017, there were $2.995 \pm 0.030$ among 1000 women of reproductive age (4.072 $\pm 0.007 \%$ in Ukraine) (according to the Ministry of Health of Ukraine), and this figure is far from realistic even according to the MI KRC KRCMCHD (6.223 $\pm 0.909 \%)$, in particular, in Russia and the USA this figure is $8-15 \%$, in Europe - about $10 \%$, in Canada - $17 \%$, in Iran - $8 \%$, in Kazakhstan - about $15 \%[2,4]$.

Endometriosis occurred only in $1.270 \pm 0.018$ per 1000 working women $(3.266 \pm 0.006 \%$ in Ukraine, respectively), which also differs from the global indicators. For example, around 176 million women between the ages of 15 and 49 are estimated to suffer from endometriosis worldwide [1]. Endometriosis affects $10-15 \%$ of all women of reproductive age and is observed in $70 \%$ of women with chronic pelvic pain [9]. In $47 \%$ of women with endometriosis-associated infertility are diagnosed with endometrial polyps [7, 15, 20].

$\mathrm{RR}$ calculations show that the largest difference between the indicator in the Kyiv region and the Ukrainian level was recorded for endometriosis (Fig. 1,2). It is this pathology that needs the most attention, although in this case it is necessary to exclude the fact of insufficient diagnosis, but a positive point should be noted some increase in this indicator over time.

Therefore, according to the results of the calculation of $\mathrm{RR}$, the appearance of gynecological pathology in the Kyiv region requires the greatest attention to the improvement of diagnostic and treatment measures for the problem of endometriosis and infertility. The situation with the latter may change when attracting data from private reproductive medicine clinics located in the region and Kyiv.

Increased RR incidence of urogenital mycoplasmosis 
and chlamydial infection in the region as opposed to decreased in Ukraine in 2010-2013 compared to 2014-2017 may be explained by the fact that, in contrast to other regions in the Kyiv region, the examination of persons of reproductive age for TORCH infection continues which, according to the results of genetic monitoring, during 1999-2003 were identified as priority risk factors for the occurrence of reproductive losses of genetic etiology $[10,18]$.

In the future, it is necessary to carry out an analysis in each individual region of Ukraine on a similar principle, which will allow to determine priority directions and rationalize the work of the obstetric and gynecological service of each investigated area.

\section{Conclusions}

1. The relative risk of gynecological diseases among women of the Kyiv region in 2014-2017 compared to 20102013 is similar to the situation in Ukraine, except for the increased relative risk of the prevalence of infertility and incidence of urogenital mycoplasmosis and chlamydial

\section{References}

1. Adamyan, L., \& Aznaurova, Y. (2015). Molecular aspects of the pathogenesis of endometriosis. Reproduction Issues, 21(2), 66-77. doi: 10.17116/repro201521266-77

2. Aghajanova, L. (2017). Obstetrics and gynecology residency and fertility needs: national survey results. Reproductive sciences, 24(3), 428-434. doi: 10.1177/1933719116657193

3. Canadian Cancer Society's Advisory Committee on Cancer Statistics. (2015). Canadian Cancer Statistics 2015. Toronto, ON: Canadian Cancer Society.

4. Dupree, J. M. (2016). Insurance coverage for male infertility care in the United States. Asian Journal of Andrology, 18(3), 339-341. doi: 10.4103/1008-682X.177838

5. French, C. E., Hughes, G., Nicholson, A., Yung, M., Ross, J. D., Williams, T., \& Soldan, K. (2011). Estimation of the rate of pelvic inflammatory disease diagnoses: trends in England, 2000-2008. Sexually transmitted diseases, 38(3), 158-162. doi: 10.1097/OLQ.0b013e3181f22f3e

6. Gavin, L, Moskosky, S, Carter, M, Curtis, K, Glass, E, Godfrey, E. \& Zapata L. (2014). Providing quality family planning services: Recommendations of CDC and the US Office of Population Affairs. Morbidity and Mortality Weekly Report, 63, 1-54.

7. Kim, M. R., Kim, Y. A., Jo, M. Y., Hwang, K. J., \& Ryu, H. S. (2003). High frequency of endometrial polyps in endometriosis. The Journal of the American Association of Gynecologic Laparoscopists, 10(1), 46-48. doi: 10.1016/s10743804(05)60233-2.

8. Munro, M. G., Critchley, H. O. D., Fraser, I. S., Haththotuwa, R., Kriplani, A., Bahamondes, L., \& Warner, P. (2018). The two FIGO systems for normal and abnormal uterine bleeding symptoms and classification of causes of abnormal uterine bleeding in the reproductive years: 2018 revisions. International Journal of Gynaecology and Obstetrics, 143(3), 393-408. doi: 10.1002/ijgo. 12666

9. Parasar, P., Ozcan, P., \& Terry, K. L. (2017). Endometriosis: epidemiology, diagnosis and clinical management. Current Obstetrics and Gynecology Reports, 6(1), 34-41. doi: 10.1007/ s13669-017-0187-1

10. Pozmogova, N., Lynchak, O., Pokanvich, T., Protsyuk, O., infection in the region. An assessment of the relative risk of gynecological pathology in the area shows that the greatest attention is needed to improve the diagnosis of infertility and endometriosis, as well as the prevention and treatment of salpingitis and uterine cancer.

2. Adenomyosis (5.7 \% vs. $2.8 \%, p=0.08)$ and hyperproliferative pathology ( $10.8 \%$ vs. $3.1 \%, p<0.01)$ were more frequently reported in women with menstrual dysfunction than those who had menstrual cycles within normal range, incl. separately endometrial hyperplasia and uterine polyps, especially among women 19-34 years.

3. It was found that in the presence of inflammation of the pelvic organs, women had a history of artificial abortion $(24.2 \%$ vs. $16.3 \%, p<0.01)$, cervical dysplasia (19.8\% vs. $4.7 \%, p<0.001)$, chronic diseases of the genitourinary system $(7.1 \%$ vs $3.2 \%, p<0.05)$ and chronic diseases of the digestive system $(17.3 \%$ vs $9.6 \%, p<0.01)$ than those examined without evidence of inflammation, which may indicate an important etiological role of the inflammatory factor in the development of gynecological pathology.

Revenko, O., \& Timchenko, O. (2009). Officials formulating genetically enumerated reproductive careers. Hygienic populations: collection of scientific works, 53, Kiev.

11. Rekart, M. L., Gilbert, M., Meza, R., Kim, P. H., Chang, M., Money, D. M., \& Brunham, R. C. (2013). Chlamydia public health programs and the epidemiology of pelvic inflammatory disease and ectopic pregnancy. The Journal of Infectious Diseases, 207(1), 30-38. doi: 10.1093/infdis/jis644

12. Revenko, O., Lynchak O., Brezitska N., Zhuravlova L., Pokanvich T., \& Vovchenko, L. (2011). The characteristics of the gynecological history of the women of the Kiev region are deceitful, when they have an apparent manifestation of a temporary distortion. V. Germanov (Ed.). Actual problems of obstetrics and gynecology, clinical and immunology and medical genetics, 21, 242-250.

13. Ross, J. D., \& Hughes, G. (2014). Why is the incidence of pelvic inflammatory disease falling? British Medical Journal, 348, 1538. doi: $10.1136 / \mathrm{bmj} . g 1538$

14. Royal College of Obstetricians\&Gynaecologists (2016). Management of Endometrial Hyperplasia. Green-top Guideline, 67.

15. Shen, L., Wang, Q., Huang, W., Wang, Q., Yuan, Q., Huang, Y., \& Lei, H. (2011). High prevalence of endometrial polyps in endometriosis-associated infertility. Fertility and Sterility, 95(8), doi: 2722-2724. 10.1016/j.fertnstert.2011.04.067

16. State Statistics Service of Ukraine (2018). The population of Ukraine for 2017 is the demographic yearbook. Kiev. State Statistics Service of Ukraine (2018). Population Yearbook "Population of Ukraine" for 2017. Kyiv.

17. The American College of Obstetricians and Gynecologists (2015). Endometrial intraepithelial neoplasia. Committee Opinion, 631. Obstetrics \& Gynecology, 125, 1272-1278.

18. Timchenko, O. I., Yelagin, V. V., Pokanevich, T. M., \& Lynchak, O. V. (2003). Assessment of risk factors for genetic disorders among the population of the Kyiv region. Anthropogenicallychanged environment of Ukraine: risk to public health and ecological systems. Special issue "Ecological Bulletin", 225236. 
19. Timchenko, O. I., Serdyuk, A. M., \& Kartashova, S. S. (2008). Gene pool and health: developing an assessment methodology. K.: Medinform. ISBN 978-966-409-042-8.

20. Tikhonchuk, E. Yu., Asaturova, A. V., \& Adamyan, L. V. (2016). The frequency of detection and structure of pathological changes in the endometrium in women of reproductive age with genital endometriosis. Obstetrics and gynecology, 12, 87-95. doi:10.18565/aig.2016.12.87-95
21. WHO Regional Committee for Europe (2016). Action Plan for Sexual and Reproductive Health: Towards achieving the 2030 Agenda for Sustainable Development in Europe - leaving no one behind. Copenhagen, Denmark.

22. Zdolnik, T. D., \& Gorbich, V. F. (2008). Environmental epidemiology. Textbook: in 2 parts. Ryazan: Ryazan State University named after S.A. Esenin

\section{ОСОБЛИВОСТІ ГІНЕКОЛОГІЧНОЇ ПАТОЛОГІЇ У ЖІНОК РЕПРОДУКТИВНОГО ВІКУ - МЕШКАНОК КИЇВСЬКІЙ ОБЛАСТІ} Горбань Н. Є., Дзісь Н. П., Линчак О. В., Поканевич Т. М.

Однією з головних умов народження здорової дитини є гінекологічне здоров'я матері. Саме тому метою роботи стала оцінка стану гінекологічного здоров'я жінок Київської області. В роботі використані дані відомчої статистичної звітності МОЗ України щодо кількості випадків гінекологічної патології за 2010-2017 рр. Кількість жінок відповідного віку визначали за даними Державної служби статистики України. Оцінювали відносний ризик виникнення патології (з урахуванням 95 \% довірчого інтервалу) у 2010-2013, 2014-2017 рр. в Київській області порівняно із загальними показниками України та у 20142017 рр. порівняно з 2010-2013 рр. в Київській області та загалом в Україні. Окремо для Київської області визначали частоту гінекологічної патології серед жінок фертильного віку (707 жінок), які звернулися до Комунального закладу Київської обласної ради "Київський обласний центр охорони здоров'я матері та дитини" за період 2014-2017 рр. Середній вік жінок становив 31,66 0,37 роки. Найчастіше у мешканок Київської області визначали хронічні запальні захворювання органів малого таза (сальпінгіти, 21,6%о). Визначені відносні ризики виникнення таких захворювань в області, порівняно з Україною, та в динаміці. В обстежених, які мали порушення менструального циклу, частіше реєстрували гіперпроліфреративні процеси ендометрія (10,8 \% проти 3,1\%, p<0,01), а у тих, хто мав запальний прочес органів малого таза, частіше зустрічалась дисплазія шийки матки (19,8 \% проти 4,7 \%, p<0,001), хронічні хвороби сечостатевої системи $(7,1 \%$ проти 3,2\%, p<0,05) та органів травлення $(17,3 \%$ проти 9,6\%, p<0,01), що свідчить про патогенетичну роль запального фактора у розвитку гінекологічної патології. Оцінка відносного ризику виникнення гінекологічних захворювань серед жінок Київської області показала, що найбільщої уваги потребує покращання діагностики безплідності та ендометріозу, а також профрілактика та лікування сальпінгітів та раку тіла матки. При зверненні жінок з порушенням менструального циклу до гінеколога необхідно звертати увагу на наявність у них гіперпроліферативної патології, а при наявності у жінки інших хронічних захворювань пропонувати санацію цих вогнищ, що може в подальшому позитивно вплинути на їх репродуктивне здоров'я.

Ключові слова: гінекологічна патологія, репродуктивне здоров'я, порушення менструального циклу, запальний фактор.

\section{ОСОБЕННОСТИ ГИНЕКОЛОГИЧЕСКОЙ ПАТОЛОГИИ У ЖЕНЩИН РЕПРОДУКТИВНОГО ВОЗРАСТА - ЖИТЕЛЬНИЦ КИЕВСКОЙ ОБЛАСТИ \\ Горбань Н. Е., Дзись Н. П., Линчак О. В., Поканевич Т. М.}

Одним из главных условий рождения здорового ребенка является гинекологическое здоровье матери. Именно поэтому целью работы явилась оценка состояния гинекологического здоровья женщин Киевской области. В работе использованы данные ведомственной статистической отчетности МОЗ Украины о количестве случаев гинекологической патологии за 2010-2017 ге. Количество женщин соответствующего возраста определяли по данным Государственной службы статистики Украины. Оценивали относительный риск возникновения патологии (с учетом 95 \% доверительного интервала) в 20102013, 2014-2017 ге. в Киевской области по сравнению с общими показателями по Украине и в 2014-2017 ге. по сравнению с 2010-2013 г2. в Киевской области и общими данными Украины. Отдельно для Киевской области определяли частоту гинекологической патологии среди женщин фрертильного возраста (707 женщин), которые обратились в коммунальное учреждение Киевского областного совета "Киевский областной центр охраны здоровья матери и ребенка" за период 20142017 г2. Средний возраст женщин составлял 31,66士0,37 года. Чаще всего у жительниц Киевской области определяли хронические воспалительные заболевания органов малого таза (сальпингиты, 21,6 \%). Определены относительные риски возникновения таких заболеваний в области, по сравнению с Украиной, и в динамике. У обследованных, которые имели нарушения менструального цикла, чаще регистрировали гиперпролиферативные процессы эндометрия (10,8 \% против 3,1 $\%, p<0,01)$, а у тех, кто имел воспалительный процесс органов малого таза, чаще встречалась дисплазия шейки матки $(19,8$ \% против 4,7 \%, p<0,001), хронические заболевания мочеполовой системы $(7,1 \%$ против 3,2 \%, p<0,05) и органов пищеварения $(17,3$ \% против 9,6 \%, p<0,01), что свидетельствует о возможной патогенетической роли воспалительного фрактора в развитии гинекологической патологии. Оценка относительного риска возникновения гинекологических заболеваний среди женщин Киевской области показала, что наибольшего внимания требует улучшение диагностики бесплодия и эндометриоза, а также профилактика и лечение сальпингитов и рака тела матки. При обращении женщин с нарушением менструального цикла к гинекологу следует обращать внимание на наличие у них гиперпролифреративной патологии, а при выявлении у женщины других хронических заболеваний - предлагать санацию этих очагов, что может в дальнейшем положительно отразиться на их репродуктивном здоровье.

Ключевые слова: гинекологическая патология, репродуктивное здоровье, нарушения менструального цикла, воспалительный фрактор. 